\title{
Payroll Taxes, Social Insurance and Business Cycles
}

Michael C. Burda* Mark Weder**

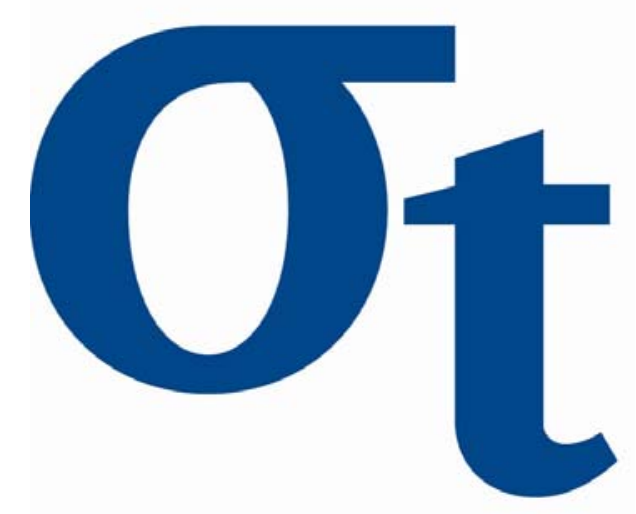

This research was supported by the Deutsche Forschungsgemeinschaft through the SFB 649 "Economic Risk". 


\title{
Payroll Taxes, Social Insurance and Business Cycles
}

\author{
Michael C. Burda* \\ Humboldt Universität zu Berlin \\ 10099 Berlin \\ Germany
}

\author{
Mark Weder \\ University of Adelaide \\ Adelaide SA 5005 \\ Australia
}

August 20, 2010

\begin{abstract}
Payroll taxes represent a major distortionary influence of governments on labor markets. This paper examines the role of payroll taxation and the social safety net for cyclical fluctuations in a nonmonetary economy with labor market frictions and unemployment insurance, when the latter is only imperfectly related to search effort. A balanced social insurance budget renders gross wages more rigid over the cycle and, as a result, strengthens the model's endogenous propagation mechanism. For conventional calibrations, the model generates a negatively sloped Beveridge curve as well as substantial volatility and persistence of vacancies and unemployment.
\end{abstract}

* Keywords: Business cycles, labor markets, payroll taxes, unemployment, consumptiontightness puzzle. JEL Classification: E24, J64, E32. We are grateful to Chris Edmond, Francisco Gonzalez, Bob Gregory, Dan Hamermesh, Tom Krebs, Nir Jaimovich, Ian McLean, Christian Merkl, Alex Meyer-Gohde, Bruce Preston, Dennis Snower, Lutz Weinke, Jake Wong and to seminar participants at ANU, Humboldt, Kiel, Mannheim, Melbourne, Utrecht, EALE/SOLE 2010 and SED 2010 for very useful comments. Patrick Bunk, Hong Lan and Susanne Schöneberg provided excellent research assistance. The authors acknowledge generous support from the Alexander von Humboldt Foundation, the Netherlands Institute of Advanced Study, and the Collaborative Research Center 649 of the German Science Foundation. 


\section{Introduction}

Payroll taxes represent a major influence of governments on labor markets. In 2005, OECD member governments collected about $\$ 3$ trillion from employers and employees, representing 9.2 percent of GDP and, given a wage share of two-thirds, roughly 15 percent of the total wage bill. In some European countries, the share of "contributions to social insurance" in total compensation is as high as 40 to 45 percent. ${ }^{1}$ Payroll taxes drive a wedge between the hiring decisions of firm and the labor supply decisions of households, and are likely to spur the untaxed, informal economy. A less-studied aspect is the effect of time-varying labor taxation on intertemporal decisions of employers and employees. Not only do payroll taxes impact the long-run functioning of labor markets and the macroeconomy, but they may also affect the magnitude and persistence of business cycle fluctuations.

This paper investigates the interaction of payroll taxes, the social insurance system and the business cycle. We begin with an empirical examination of the cyclical behavior of payroll taxation. We find evidence that payroll taxation is countercyclical in a number of OECD countries: employer and employee contributions to social insurance, measured relative to the total wage bill, tend to fall in recoveries and rise in recessions. This countercyclical labor tax burden arises for at least two reasons. First, most OECD governments rely on payroll taxation to fund their social welfare systems, sometimes on a near-balanced budget basis. Second, payroll taxation is usually capped, implying a relatively higher effective rate of taxation for low-productivity workers at the extensive margin.

Next, we study the effects of countercyclical payroll taxation in an equilibrium business cycle model with labor market frictions. We show that in

\footnotetext{
${ }^{1}$ Source: OECD Revenue Statistics 2007.
} 
this class of models, the elasticity of search activity on both sides of the market is influenced by the intertemporal path of the wedge between costs paid by firms and income received by households. The endogeneity of the tax burden to cyclical conditions reinforces the intertemporal response of labor market activity and thus increases the endogenous propagation of shocks in the model economy. By distinguishing between search and leisure, we account for the possibility that non-working time is not used for active search and create an additional margin for time use. There are two other features central to the model: unemployment benefits are financed by payroll taxation on a balanced budget basis and unemployment benefit provision is only imperfectly related to search effort. ${ }^{2}$ This latter is due to the extent of general social welfare in the model economy, which is can be thought of as "Type II" classification error - paying unemployment benefits to those in fact taking leisure. Combined with the endogeneity of labor taxation, these effects significantly distort the labor-search-leisure decision and increase the internal propagation of the model economy.

Although models with labor market frictions have proliferated in recent years, Shimer (2005) and Hall (2005) showed that they generally do not generate sufficient volatility and persistence in labor market quantities, i.e. vacancies and unemployment. They argue that wage rigidity is the most promising solution to the puzzle. To this end, Hagedorn and Manovskii (2008) raise the fallback position and lower the bargaining power of workers in wage bargaining (see also Cole and Rogerson, 1999), while Gertler and Trigari (2009) employ overlapping Nash-bargained wage contracts. Hornstein, Krusell and Violante (2005) and Costain and Reiter (2008) and show that these approaches, however successful, can generate a number of unwanted

\footnotetext{
${ }^{2}$ Tripier (2003), Ravn (2008) and Ebell (2009) examine similar setups, but they do not examine the impact of unemployment benefit on the search-leisure margin and do not consider unemployment benefits financed by distortionary payroll taxation.
} 
side effects. ${ }^{3}$ Ravn (2008) shows that with endogenous participation, the search model predicts a counterfactual positively-sloped Beveridge relation and procyclial unemployment.

The central finding of this paper is that the interaction of endogenous payroll taxation with the social insurance system can reduce the volatility of gross labor costs in a real equilibrium business cycle model and match key macro stylized facts, which include persistence in vacancies, high cyclical volatility of labor market quantities, and negative correlation of vacancies and unemployment (the Beveridge curve). Time-varying payroll taxes affect the both cost of labor and the value of vacancies to the firm, as well as the value of time spent by workers in search. This intertemporal effect of taxes on equilibrium models of unemployment is also a novel finding.

In Section 2, we document the level and intertemporal behavior of payroll taxes in the major OECD countries. For a number of Western European economies (Finland, France, and Germany in particular), effective payroll taxes are significantly countercyclical; in the United States, a similar pattern has also emerged in the last two decades. Section 3 lays out a nonmonetary dynamic stochastic general equilibrium economy with a social insurance system, unemployment benefits and endogenous search. The model is calibrated in Section 4, while Section 5 presents our central finding: a productivitydriven real equilibrium economy with search frictions can account for labor market facts and generate a pattern of countercyclical payroll tax burdens observed in many OECD countries. Robustness checks and more detailed interpretation of the results are laid out in Section 6. Section 7 concludes.

\footnotetext{
${ }^{3}$ Sticky wages are not easy to find in the data (Bils 1985), and the standard model predicts a counterfactually strong negative correlation between the labor share and labor productivity. Hall and Milgrom (2008) note that high values of fallback induce unrealistically high elasticities of labor supply response. More recent work by Shimer (2009) and others show how intratemporal non-separability in utility over consumption and nonwork can induce similar effects.
} 


\section{Payroll taxes in the OECD}

\subsection{Magnitude of payroll taxes}

Payroll taxation represents a significant, yet frequently overlooked intervention in labor markets in developed economies. In 2008, the total contribution of households and enterprises to social security (i.e. payroll taxes) represented 33.7 percent of total compensation in Germany and 25.2 percent in Sweden, as compared with 11.3 percent in the United States. Table 1 reports a longer-term perspective on payroll taxation. The payroll tax rate $(\tau)$ is defined as the ratio of all "contributions to social insurance" divided by total compensation of employees, and represents the average burden posed by payroll taxes and other social contributions as a fraction of total labor costs paid by firms. Our data are taken from the OECD Economic Outlook and Main Economic Indicators databases. Contributions to social insurance consist of payments by firms or employees for pension, health, unemployment and disability insurance, and some other minor elements of social insurance. Total compensation is defined as gross wages, salaries and other payments made by employers on behalf of their employees. The first two columns of the table document levels and trends of payroll taxation in countries for which longer time series are available.

The average effective payroll tax rate thus varies widely in OECD countries, ranging from $5-15 \%$ of the wage bill in Canada, the US and Finland to $30 \%$ or more in France, Germany and Sweden. As evident from Figures 1 and 2, they also vary over time. Over the four decades of data available, average taxes have risen secularly in almost all countries. At the same time, they fluctuate around their respective trends, with standard deviations of less than 0.2 percentage points in the US and Canada to more than $0.6 \%$ in Sweden, France, Finland, Greece, and the Netherlands. Such fluctuations of 
tax burdens are likely to important for labor markets, not only in continental Europe, but also in the United States.

\begin{tabular}{|l|c|c|c|c|c|}
\hline Table 1: Payroll taxes in OECD countries \\
\hline \multirow{3}{*}{ Country } & $\begin{array}{l}\text { Ratio of payroll taxes } \\
\text { to total compensation }\end{array}$ & $\begin{array}{l}\text { Correlation of payroll tax rate } \\
\text { with GDP* }\end{array}$ \\
\cline { 2 - 6 } & $1970-89$ & $1990-08$ & $1970: 1-89: 4$ & $1990: 1-08: 4$ & $1970: 1-08: 4$ \\
\hline US & 0.10 & 0.12 & 0.23 & -0.28 & 0.15 \\
\hline Germany & 0.28 & 0.34 & -0.48 & -0.56 & -0.51 \\
\hline Netherlands & 0.29 & 0.29 & -0.13 & -0.03 & -0.10 \\
\hline UK & 0.23 & 0.26 & 0.12 & 0.04 & 0.10 \\
\hline Sweden & 0.25 & 0.32 & -0.42 & 0.36 & 0.09 \\
\hline France & 0.37 & 0.41 & -0.04 & -0.39 & -0.23 \\
\hline Japan & 0.17 & 0.24 & -0.39 & -0.10 & -0.26 \\
\hline Canada & 0.06 & 0.09 & -0.27 & -0.07 & -0.21 \\
\hline Finland & 0.14 & 0.17 & -0.53 & -0.48 & -0.47 \\
\hline $\begin{array}{l}\text { Source: OECD, authors' calculations based on quarterly data } \\
\text { *Real GDP and tax rates are HP-filtered with smoothing parameter } \lambda=1600 .\end{array}$ \\
\hline
\end{tabular}

\section{$2.2 \quad$ Function of payroll taxes}

Payroll taxes are primarily used to fund social security systems. This concept of social insurance dates to social reforms in late-nineteenth century Germany, which served as a model for many industrial countries, including the United States. ${ }^{4}$ This type of social system is characterized by a relatively

\footnotetext{
${ }^{4}$ In an effort to deflect criticism of rising inequality in a time of rapid growth, Chancellor Bismarck initiated wide-reaching reforms during the 1880s, culminating in the Health Insurance Act of 1883 (Gesetz betreffend die Krankenversicherung der Arbeiter), the Accident Insurance Act of 1884 (Unfallversicherungsgesetz) and the Old Age and Disability Insurance Act of 1889 (Gesetz betreffend der Invaliditäts- und Altersversicherung). These were important first pillars of the current German social insurance system, which were augmented in 1927 by the Law on Employment and Unemployment Insurance (Gesetz über Arbeitsvermittlung und Arbeitslosenversicherung).
} 
low level of explicit redistribution; health, pension, and unemployment insurance funds are established to honor entitlements based on past service or accrued eligibility. In theory, workers and firms contribute towards the costs of social insurance programs, which run on a near-balanced budget basis. Funding of such programs is thus susceptible to business cycle fluctuations, with cyclical adjustments often required to bring contributions in line with outlays.

As a representative example, consider Germany's current system of unemployment benefits, which was established in 1969 by the Employment Promotion Act (Arbeitsförderungsgesetz). This law set up the Federal Employment Agency (Bundesagentur für Arbeit) to provide income support for unemployed as well as training and support in job finding and matching. The activities of the agency are funded primarily by payroll tax contributions. The government provides stop-gap assistance only under exceptional circumstances in the form of interest-free liquidity loans, which are generally repaid as soon as income exceeds spending in any given month. As a result, contribution rates vary considerably over time and are often reduced in times of stronger economic growth, and raised in recessions. ${ }^{5}$ Similar funding principles apply to other pillars of the social security system (health, pension, disability, old-age care, etc.).

The Bismarckian system stands in contrast to the concept of social insurance promoted by Beveridge in the late 1940s and based on the notion of a sufficient minimum benefit to be funded by the general public budget if necessary. In many European countries, deficits in social security programs

\footnotetext{
${ }^{5}$ In the period 2007-2009, for example, the statutory contribution rate for the German unemployment insurance scheme decreased from 6.5 percent of gross eligible wage income to 2.8 percent. In the recession which followed, tax increases for unemployment insurance were avoided only by a discretionary expansion of the short-time work program, which exempts employees from social insurance contributions.
} 
are regularly covered by budgetary transfers. The social security system of old-age benefits in the United States combines Bismarckian and Beveridgean elements. It is funded by payroll taxes, with employers withholding $6.2 \%$ of employee wages and matching that amount in employer social security taxes until total earnings reach a fixed earnings base (ceiling) for the year. above which no further tax is levied. Romer and Romer (2009) document that US Social Security tax increases tend to be preprogrammed and follow increases in benefits, either in the form of increasing statutory rates or increases in the payroll tax base.

\subsection{Cyclical behavior of payroll taxes}

For at least two reasons, the average payroll tax rate $\tau$ - and thus the tax burden for the representative worker moving from unemployment into employment - is likely to be countercyclical. In recessions, budget shortfalls are difficult to close, especially when social expenditures have the nature of entitlements. As a result, tax rates may be raised in recessions and cut in expansions. While we focus on unemployment insurance and welfare benefits, countercyclical funding issues arise in systems of health services, public pensions and social programs in general. A second reason for countercyclical payroll tax rates is the truncated nature of payroll tax systems in most OECD countries, in which a cap on contributions limits total tax liability of employers for a given employee. ${ }^{6}$ In expansions, when overall wages and productivity are rising, more workers will earn gross pay exceeding the contributions cap, while in recessions, new jobs tend to pay less.

\footnotetext{
${ }^{6}$ In the United States, the ceiling on social security contributions, which is adjusted annually for inflation, was $\$ 102,000$ in 2008 . This represents the roughly the 85 th percentile of the annual gross household income distribution in the US. In Germany, the ceiling was 5300 Euro per month in 2008. At the lower end of the pay spectrum, so-called Mini-Jobs (defined as jobs that pay less than 400 Euro per month) face a significantly lower payroll $\operatorname{tax}$.
} 
Figures 3 and 4 and the last three columns of Table 1 document that the average effective payroll tax rate $\left(\tau_{t}\right)$ is not constant. In fact, it is strongly countercyclical in Germany, France, and the Netherlands, while less so in Sweden, the UK and the United States. To remove low frequency movements in the data, we applied the HP-filter to the payroll tax and real GDP series. The overall contemporaneous correlation of the payroll tax rate and the business cycle in the period 1990-2008 was -0.56 in Germany, -0.39 in France, and -0.48 in Finland. While payroll taxation is acyclical in the United States over the entire period, it has become more negatively correlated with the cycle over the last two decades. ${ }^{7}$ Our finding is consistent with the conclusion of the business cycle accounting literature and its concept of the "labor wedge" (see Chari, Kehoe and McGrattan, 2008), although researchers in this area have tended to focus on distortions based on government regulation and other market imperfections. Rogerson and Shimer (2010) and Shimer (2009) argue that the labor wedge moves countercyclically, that is, in the same direction as our payroll tax measure. ${ }^{8}$

\section{Figures 1, 2, 3, and 4 about here}

Evidently, policy can influence the sign of this correlation by breaking the rigid link between payroll taxation and the business cycle which results from a balanced budget rule. Already in the 1930s, Kaldor (1936) and Meade (1938) proposed setting payroll taxes to covary positively with the state of the economy, and their ideas were endorsed by Keynes (1942) and Beveridge (1944). In smaller, open OECD countries such as the Netherlands and Sweden, discretionary policy seems to have reduced the anticyclicality of payroll

\footnotetext{
${ }^{7}$ This finding is not an artifact of the detrending procedure. With first-differenced data, the correlation in the US declines over the two subperiods from 0.36 to -0.48 .

${ }^{8}$ The correlation between HP-detrended versions of Shimer's (2009) wedge measure and our average payroll tax rate is 0.52 for the period 1990-2006 (for the period 1970-2006 it is only 0.10$)$.
} 
taxes or even made them procyclical. The increasing countercyclical behavior of the US payroll tax rate may also be due to increasing procyclicality in both levels and variance of wages, given the contributions cap. ${ }^{9}$

In the next section, we examine the effect of payroll taxation in a dynamic stochastic general equilibrium model of the business cycle with labor market frictions along the lines of Tripier (2003), Veracierto (2008), and Ravn (2008), to which systems of unemployment benefits and social assistance funded by distortionary labor taxation are added. To emphasize the effects on dynamics, we will study the extreme case of a balanced-budget version of the model, in which payroll taxes are set passively by the government to fund unemployment benefit and social assistance payments due each period.

\section{An equilibrium business cycle model with payroll taxation}

\subsection{Labor market search}

Subscripts refer to periods of discrete time $t \geq 0$. The economy is populated by a large number of infinitely-lived, identical consumer-worker households of measure one. Each household consists of a large number of individuals who derive utility from consumption and leisure. Workers (or family members) can spend their nonworking time in active unemployment (i.e., searching) or in leisure. If we normalize non-sleeping time to unity, the representative agent faces the following time budget:

$$
h_{t}+s_{t}+\ell_{t}=1
$$

where $h_{t}, s_{t}$, and $\ell_{t}$ are working time, search time, and leisure (which could include home production). The threefold use of time reflects our interest in

\footnotetext{
${ }^{9}$ See Gali and van Rens (2010) for evidence on the United States.
} 
the distinction between search and voluntary unemployment and its interaction with labor market interventions described above: payroll taxes and social insurance. ${ }^{10}$ Governments payroll tax receipts are used to subsidize search (unemployment benefits) and leisure (social welfare payments).

Workers and jobs search for each other in a decentralized labor market. ${ }^{11}$ Matching is modeled as a constant returns function of workers' search activities, $s_{t}$, and firms' posted vacancies, $v_{t}$, in the form of a matching function, $M\left(s_{t}, v_{t}\right)=s_{t}^{\eta} v_{t}^{1-\eta}$. At the same time, filled jobs are broken up each period at a constant rate, $\delta^{h}$, with $0<\delta^{h}<1 .{ }^{12}$ In the absence of onthe-job search, the vacancy-unemployment ratio $\theta_{t} \equiv v_{t} / s_{t}$ is a sufficient statistic of market tightness. The vacancy placement rate $q_{t}$, is linked to the job-finding rate among the searching unemployed $f_{t}$, by the relation $q_{t}=\frac{M\left(s_{t}, v_{t}\right)}{v_{t}}=M\left(\frac{s_{t}}{v_{t}}, 1\right)=\frac{M\left(1, \theta_{t}^{-1}\right)}{\theta_{t}}=\frac{f_{t}}{\theta_{t}}$. Employment $h_{t}$, is a state variable for the household. From the perspective of the individual searcher, $f_{t}$ is the probability that a match will occur. For the aggregate economy, employment thus obeys

$$
h_{t+1}=s_{t} f_{t}+\left(1-\delta^{h}\right) h_{t}
$$

Similarly, $q_{t}$ is the probability that an open vacancy will be matched in a period (the job matching rate per vacancy posted) so the following aggregate relationship also holds:

$$
h_{t+1}=v_{t} q_{t}+\left(1-\delta^{h}\right) h_{t} .
$$

\footnotetext{
${ }^{10}$ Without loss of generality it is possible to modify this model to reflect more standard time use assumptions as well as costly labor market state switching.

${ }^{11}$ See Merz (1995) and Andolfatto (1996) for the seminal contributions in this literature.

${ }^{12}$ Shimer (2005) argues that the cyclical variability of separations is dominated by that of outflows from unemployment.
} 


\subsection{Social insurance}

The government collects social security contributions from gross factor payments to labor, $w_{t} h_{t}$, at rate $\tau_{t}$. Government purchases of goods and services are suppressed, so all revenues from payroll taxes are used to finance a fixed unemployment benefit $b$ paid to $s_{t}$ unemployed engaged in search, and $\varepsilon b$, paid to $\left(1-s_{t}-h_{t}\right)$ household members enjoying leisure. The parameter $\varepsilon \in(0,1)$ can be interpreted alternatively as a measure of "classification error", malfeasance in the unemployment system, or overall generosity of the welfare state. ${ }^{13}$ A positive $\varepsilon$ means that household members not actively searching still receive some social support, which is characteristic of many OECD social security systems. The government adjusts the payroll tax rate in each period to respect the budget constraint

$$
b s_{t}+\varepsilon b\left(1-s_{t}-h_{t}\right)=\tau_{t} w_{t} h_{t} .
$$

As $\varepsilon$ approaches 1, search time and leisure are "rewarded" equally in terms of consumption goods. As $\varepsilon$ approaches zero, the system replicates the standard model, and leisure is not rewarded beyond its intrinsic utility value to individual households. Writing the payroll tax rate as

$$
\tau_{t}=\frac{(1-\varepsilon) b s_{t}+\varepsilon b\left(1-h_{t}\right)}{w_{t} h_{t}},
$$

we see that a sufficient condition for countercyclical $\tau_{t}$ is for $w_{t}$ and $h_{t}$ to be procyclical and $s_{t}$ countercyclical.

\subsection{Households}

Households choose their labor and capital market activities to maximize expected utility. Their labor $h_{t}$ is compensated at net rate $\left(1-\tau_{t}\right) w_{t}$. They

\footnotetext{
${ }^{13}$ See Burda and Weder (2002) for a similar formulation.
} 
own the capital stock used in production, $k_{t}$ and rent capital services deriving from it, $\kappa_{t}$, to firms in a competitive market. These capital services are defined as the product of the capital stock and its utilization rate, $u_{t}$, i.e. $\kappa_{t}=u_{t} k_{t}$. The owners of capital choose $\kappa_{t}$ and $u_{t}$ subject to the dependence of depreciation on capital utilization

$$
\delta_{t}^{k}=\frac{1}{\omega} u_{t}^{\omega}
$$

where $\omega>1 .^{14}$

Given sequences of market real wages, $\left\{w_{t}\right\}$, and rental rates for capital services, $\left\{r_{t}\right\}$, the problem faced by a representative household at $t=0$ is to choose sequences of consumption $\left\{c_{t}\right\}$, search time $\left\{s_{t}\right\}$, labor $\left\{n_{t}\right\}$, capital tomorrow $\left\{k_{t+1}\right\}$ and capital utilization $\left\{u_{t}\right\}$ to maximize expected utility

$$
E_{0} \sum_{t=0}^{\infty} \beta^{t}\left[\ln c_{t}+A \frac{\ell_{t}^{1+\chi}}{1+\chi}\right],
$$

given initial stock of capital $\left(k_{0}\right)$ and level of employment $\left(h_{0}\right)$, the periodby-period budget constraint of the household for $t=0,1, \ldots$ :

$$
k_{t+1}+c_{t}=\left(1-\tau_{t}\right) w_{t} h_{t}+\left(1+u_{t} r_{t}-\delta_{t}^{k}\right) k_{t}+b s_{t}+\epsilon b\left(1-s_{t}-h_{t}\right),
$$

the evolution of employment (2) and the dependence of depreciation on utilization (6). It is assumed that $A>0,0<\beta<1, \chi \leq 0$.

Let $z_{t}$ stand for an exogenous stationary stochastic process which describes the state of productivity in the economy, to be made more precise below. The maximized value of expected utility given current employment, capital stock and the state of the economy, $V\left(h_{t}, k_{t} ; z_{t}\right)$, is governed by the

\footnotetext{
${ }^{14}$ Modeling depreciation as a convex function of capacity utilization is common and follows Greenwood, Hercowitz and Huffman (1988) among others. This feature is included to track GDP better and is not essential to our findings.
} 
Bellman equation for $t=0,1, .$.

$V\left(h_{t}, k_{t} ; z_{t}\right)=\max _{c_{t}, s_{t}, u_{t}, h_{t+1}, k_{t+1}} \ln c_{t}+A \frac{\left(1-s_{t}-h_{t}\right)^{1+\chi}}{1+\chi}+\beta E_{t} V\left(h_{t+1}, k_{t+1} ; z_{t+1}\right)$

subject to (2), (5) and (6), taking initial levels of employment and capital as given. Optimality is characterized by the following conditions:

$$
\begin{gathered}
\frac{1}{c_{t}}=\beta E_{t}\left[\frac{1+r_{t+1}-\delta_{t+1}^{k}}{c_{t+1}}\right] \\
r_{t}-u_{t}^{\omega-1}=0
\end{gathered}
$$

and

$$
\begin{gathered}
A\left(1-s_{t}-h_{t}\right)^{\chi}-\frac{b}{c_{t}}(1-\epsilon)=\beta f_{t} E_{t} \frac{1}{c_{t+1}}\left[w_{t+1}\left(1-\tau_{t+1}\right)-\epsilon b\right] \\
+\beta f_{t} E_{t} f_{t+1}^{-1}\left[\left(1-\delta^{h}-f_{t+1}\right) A\left(1-s_{t+1}-h_{t+1}\right)^{\chi}-\frac{b\left(1-\delta^{h}\right)(1-\epsilon)}{c_{t+1}}\right] .
\end{gathered}
$$

Condition (8) is the typical Euler equation for consumption while (9) equates the marginal return from capital utilization to its marginal (depreciation) costs. Equation (10) determines the optimal intertemporal search-labor supply sequence. The left-hand side denotes the marginal utility of leisure time lost from shifting time from non-search leisure to search activities. The right-hand side is the expected discounted marginal gain from search, which consists of the expected utility of earning $w_{t+1}\left(1-\tau_{t+1}\right)$ in wages tomorrow less $\epsilon b$, the loss of benefit received in leisure (note if $\epsilon=0$, leisure is not subsidized), plus the utility gain from not having to search tomorrow. Search activity today is also influenced by future taxes; higher expected taxes tomorrow reduces the net return from work and thus the incentive to search today. 


\subsection{Firms}

Firms maximize expected profits on behalf of their owners, the households. They produce output $y_{t}$ using a constant returns production technology

$$
y_{t}=z_{t} \kappa_{t}^{\alpha} h_{t}^{1-\alpha}
$$

Profits, $\Pi_{t}$, are given each period by

$$
\Pi_{t}=y_{t}-w_{t} h_{t}-r_{t} \kappa_{t}-a v_{t}
$$

The term $z_{t}$ denotes total factor productivity and its logarithm is assumed to follow a stationary first-order autoregressive stochastic process. Firms maximize the expected discounted value of profits, computed using the stochastic discount factor $\rho_{t+1}=\beta \lambda_{t+1} / \lambda_{t}$, by hiring capital services from households, posting vacancies at cost $a$ and, given the transition equation for employment, by choosing the volume of employment in the next period $h_{t+1}$. The maximized value of the firm given current employment and the state of the economy, $W\left(h_{t} ; z_{t}\right)$, is given by the Bellman equation

$$
W\left(h_{t} ; z_{t}\right)=\max _{\left\{\kappa_{t}, v_{t}, h_{t+1}\right\}} \Pi_{t}+E_{t}\left[\rho_{t+1} W\left(h_{t+1} ; z_{t+1}\right)\right]
$$

subject to (12) and the transition equation for employment from the firm's perspective (3).

First-order conditions for the firm for $t=0,1, .$. can be expressed as follows. Optimal choice of capital service input equates marginal product of capital services with the rental price:

$$
\alpha \frac{y_{t}}{\kappa_{t}}-r_{t}=0
$$

Optimal vacancy decisions are determined by

$$
\frac{a}{q_{t}}=E_{t} \rho_{t+1}\left[(1-\alpha) \frac{y_{t+1}}{h_{t+1}}-w_{t+1}+\left(1-\delta^{h}\right) \frac{a}{q_{t+1}}\right]
$$


which equates expected costs of posting a vacancy to the expected discounted value of profits of filling it (recursively, the marginal surplus of a match today plus vacancy costs saved if it survives to the next period).

\subsection{Wage bargaining}

The two surpluses derived above determine the joint surplus from a match between a worker and a firm. The surplus to a matched worker is $V_{h_{t}}-V_{s_{t}}$, since the fallback position of a matched worker is to resume search or spend time in leisure. At the optimum, these two alternatives yield equal utility. Optimality implies that the marginal contribution to the value of the utility maximization program of an additional unit of time in search equals zero: $V_{s_{t}}=0$. For firms, the surplus of an additional employed worker is $W_{h_{t}}-W_{v_{t}}$. At the optimum, it must also be the case that $W_{v_{t}}=0$. The joint surplus in the symmetric equilibria we will study in this model is therefore equal to $W_{h_{t}}+V_{h_{t}}$.

The wage divides match surplus between worker and firm and is determined at the individual level (we abstract completely from collective bargaining). Individual workers are hired by a representative firm, which employs many workers. Labor's bargaining power is summarized by $\mu \in[0,1]$, the Nash bargaining parameter which determines the split of the match surplus going to the worker. The surplus to the worker is

$$
V_{h_{t}}=\frac{w_{t}\left(1-\tau_{t}\right)-b}{c_{t}}+\beta\left(1-\delta^{h}-f_{t}\right) E_{t} V_{h_{t+1}}
$$

Note that as the solution to a standard Nash bargaining problem, the gross (before tax) wage is continuously renegotiated and there are no ad hoc real rigidities. In each period it solves

$$
\max _{w_{t}} \mu \ln \left(V_{h_{t}} / \lambda_{t}\right)+(1-\mu) \ln W_{h_{t}}
$$


subject to the definitions of $V_{h_{t}}$ and $W_{h_{t}}$ and taking $\lambda_{t}$ as given. In the Appendix, we show that the wage which solves this problem is given by:

$w_{t}=\frac{(1-\mu) b}{1-\tau_{t}}+\mu(1-\alpha) \frac{y_{t}}{h_{t}}+\mu\left(1-\delta^{n}\right) \frac{a}{q_{t}} \frac{E_{t}\left(\tau_{t+1}-\tau_{t}\right)}{1-\tau_{t}}+\mu \theta_{t} a \frac{E_{t}\left(1-\tau_{t+1}\right)}{1-\tau_{t}(16)}$.

While the wage is influenced by the unemployment benefit paid to searching unemployed, it is independent of the social safety net parameter $\epsilon$, given the marginal product of labor, market tightness, and the intertemporal path of taxes. For a constant profile of tax rates, the Nash-bargained wage depends positively on the level of taxes, but the extent of this forward shifting depends on worker's bargaining strength $\mu$.

One novel feature of the wage equation (16) is the central role of payroll taxation, and in particular, its intertemporal path. Ceteris paribus, a rising expected tax rate will raise the gross-of-tax wage today, while the expectation of falling payroll taxes tomorrow will cause the bargained wage to decline today. If taxes are constant at $\tau$ the wage equation reduces to

$$
w_{t}=\frac{(1-\mu) b}{1-\tau}+\mu(1-\alpha) \frac{y_{t}}{h_{t}}+\mu \theta_{t} a
$$

and if $\tau_{t}=\tau_{t+1}=0$, the expression collapses to the wage equation derived by, for example, Ebell (2008) or Ravn (2008). A second noteworthy aspect of (16) is the interaction of payroll taxation with worker bargaining power, parametrized by $\mu$. The greater workers' bargaining power, the greater will be their ability to shift taxes forward onto firms, and this also applies to the impact of the expected tax profile on wages. In addition, wages become increasingly rigid as the workers' bargaining power approaches zero, i.e., $w(1-\tau)=b$. 


\section{Equilibrium and calibration}

An equilibrium in this decentralized economy is defined as a set of sequences of wages $w_{t}$, capital rental rates $r_{t}$, capital input $\kappa_{t}$, capital stock $k_{t}$, capital utilization rate $u_{t}$, employment $h_{t}$, search $s_{t}$, vacancies $v_{t}$, output $y_{t}$, consumption $c_{t}$, investment $i_{t}$, and payroll tax rates $\tau_{t}$ which satisfy optimality conditions of households and firms, resource and budget constraints as well as a transversality condition for the capital stock, given the current values of the state variables employment, technology, and capital.

We begin by specifying the non-stochastic stationary state of this economy and its calibration, which is summarized in Table 2. Given the findings of Table 1, the German economy is a natural benchmark and we calibrate our economy average over our sample period. ${ }^{15}$ The fundamental period is a quarter.

\begin{tabular}{|l|l|}
\hline Table 2: Calibration & \\
\hline Labor share, $w h / y$ & 0.7 \\
\hline Discount factor, $\beta$ & 0.99 \\
\hline Supply elasticity of nonleisure time, $-1 / \chi$ & 0.2 \\
\hline Vacancy posting costs, $a v / y$ & 0.005 \\
\hline Capital depreciation rate, $\delta^{k}$ & 0.025 \\
\hline Job separation rate, $\delta^{h}$ & 0.06 \\
\hline Replacement rate, $b / w$ & 0.6 \\
\hline Unemployment rate & 0.07 \\
\hline Time working and searching, $h+s$ & 0.5 \\
\hline Matching elasticity, $\psi$ & 0.5 \\
\hline AR coefficient of TFP process $\left(z_{t}\right)$ & 0.95 \\
\hline
\end{tabular}

While most parameter values are standard, our calibration and the steady state solution which is implied require more detailed discussion. We set the labor share at 70 percent and assume that steady state vacancy posting costs

\footnotetext{
${ }^{15}$ See Cooley (1997) for a more detailed description of calibration methods.
} 
are half a percent of output. Our choice of $\beta$ implies an annual risk free rate of four percent; physical capital depreciates at 2.5 percent per quarter. By setting $\chi=-5$, we make labor supply less elastic than usually assumed in real business cycle models $(\chi=-1$ is associated with the log utility case). ${ }^{16}$ The model is calibrated to match the replacement rate, $b / w$, at 60 percent. This value is significantly lower than that assumed by Hagedorn and Manovskii (2008); furthermore it corresponds to values found in Germany and other Western European countries. The steady state nonsleeping leisure time $1-h-s$ is set to $1 / 2$ (Burda, Hamermesh, and Weil, 2008). The average unemployment rate is seven percent and $\tau$ is equated to the average of observed rate for Germany (30 percent). The government's steady state financing constraint

$$
\tau \frac{w h}{b}=s+\varepsilon(1-s-h)
$$

is used to fix $\varepsilon=0.41$. The firm's vacancies equation and the wage equation determine $A$ and the relative bargaining power at $\mu=0.5455 .{ }^{17}$ The elasticity parameter $\omega$ relating depreciation to capacity utilization is pinned down by the first order conditions for the household (7) and (8):

$$
\omega=\frac{1 / \beta-1+\delta^{k}}{\delta^{k}}=1.4040 .
$$

\footnotetext{
${ }^{16}$ This value is in line with micro studies of labor supply and deflects the usual criticism of the labor market in real business cycle models. We will show below that a high labor supply elasticity is not needed to induce high employment volatility.

${ }^{17}$ Note that the last parameter does not coincide with the elasticity of the matching function, hence, the Hosios (1990) condition is not satisfied in this economy. Given the severe tax and other distortions already present, it seems inappropriate to assume the efficient outcome of the search process.
} 


\section{Cyclical properties of the artificial econ- omy}

In this section, we examine the central predictions of the model with respect to macroeconomic and labor market variables. In particular, we are interested in artificial economies that display significant cyclical behavior of payroll taxes (see Table 1). To do this, we simulate the artificial economy and compare the outcome to a representative Western European economy, Germany, for which the Hall-Shimer-Ravn labor market puzzles are even more pronounced than in the US (see Gartner, Merkl and Rothe (2009)). We begin by presenting key facts regarding the correlations of vacancies, unemployment, labor market tightness and labor productivity for the German economy in Table 3. All data are quarterly, Hodrick-Prescott detrended and cover the period 1970:I to 2008:IV.

We focus attention on three important empirical regularities in Table 3. The most well-known is the Beveridge curve, the empirical negative correlation between vacancies and unemployment. Secondly, the table features the inverse relationship of unemployment and labor market tightness, which is measured as the ratio of vacancies to unemployment. This measure of tightness rises in booms and declines in recessions. Third, unemployment and labor productivity, $p$, are slightly negatively correlated; booms tend to be periods of higher labor productivity.

We begin the analysis by characterizing the dynamics of our artificial economy without payroll taxes. This model is close in spirit to those studied by Tripier (2003), Ravn (2008), and Veracierto (2008), who model distinct activities in unemployment, i.e. search versus leisure. All these authors were unable to replicate the negatively-sloped Beveridge curve, with unemploy-

ment instead fluctuating procyclically; since unemployment is equated with 
search activity, incentives to search are sufficiently procyclical to generate this counterfactual property. ${ }^{18}$ Table 4 confirms that our artificial economy which is driven by a single technology shock process - also displays this property when the payroll tax rate $\tau$ is set to zero and social insurance is financed via lump-sum taxation. Without payroll taxes, our artificial economy fails to replicate the Beveridge curve relationship, instead generating a $s-v$ correlation of 0.87 . While this version of the model predicts a positive correlation between productivity and market tightness, it is considerably stronger than in the data (model: 0.99, Germany: 0.29). Furthermore, it cannot generate the observed negative correlations between labor market tightness and labor productivity with unemployment. ${ }^{19}$

\begin{tabular}{|c|c|c|c|c|}
\hline & $\begin{array}{l}\text { e } 3 \\
\text { ucti }\end{array}$ & $\begin{array}{l}\text { abor } \\
\text { y, Geı }\end{array}$ & $\begin{array}{l}\text { narket } \\
\text { nany, }\end{array}$ & $\begin{array}{l}\text { ndicat } \\
970: I\end{array}$ \\
\hline & $v$ & $s$ & $\theta$ & $p$ \\
\hline$v$ & 1.00 & -0.81 & 0.96 & 0.30 \\
\hline$s$ & & 1.00 & -0.94 & -0.24 \\
\hline$\theta$ & & & 1.00 & 0.29 \\
\hline$p$ & & & & 1.00 \\
\hline
\end{tabular}

\begin{tabular}{|c|c|c|c|c|}
\hline & $v$ & $s$ & $\theta$ & $p$ \\
\hline$v$ & 1.00 & 0.87 & 0.61 & 0.69 \\
\hline$s$ & & 1.00 & 0.15 & 0.26 \\
\hline$\theta$ & & & 1.00 & 0.99 \\
\hline$p$ & & & & 1.00 \\
\hline
\end{tabular}

A key finding of this paper is that central robust correlations in the data are restored in the presence of payroll taxes and a self-financing social security

\footnotetext{
${ }^{18}$ Ebell (2009) shows that some of these problems can be addressed by alternative calibration assumptions.

${ }^{19}$ Ravn (2008) has called these results the "consumption-tightness puzzle." In what follows, we will show how the introduction of payroll taxation can overcome the puzzle.
} 
system. Tables 5 through 9 document these results. In Table 5 we report the same labor market correlations for the calibrated economy with a positive and endogenous payroll tax rate and a social safety net of calibrated size $(\tau=0)$. The calibrated model is qualitatively and quantitatively much more consistent with correlations from the German economy (Table 3). First, the Beveridge curve is restored, with a correlation of -0.74 , essentially the value for the German economy. Second, the model economy produces a significant increase in the volatility of vacancies and unemployment (Table 6). Furthermore, unemployment and tightness are negatively correlated: the correlation switches sign from 0.15 to -0.91 , a value which is almost identical to the correlation in the German data. Theory can now also account for a weakly negative correlation between unemployment and productivity.

\begin{tabular}{|c|c|c|c|c|}
\hline & $\begin{array}{l}\text { le } 5 \\
\text { lucti }\end{array}$ & $\begin{array}{l}\text { abor } \\
\text {, art }\end{array}$ & $\begin{array}{l}\text { larket } \\
\text { cial e }\end{array}$ & $\begin{array}{l}\text { ndicat } \\
\text { nomy }\end{array}$ \\
\hline & $v$ & $s$ & $\theta$ & $p$ \\
\hline$v$ & 1.00 & -0.74 & 0.96 & 0.68 \\
\hline$s$ & & 1.00 & -0.91 & -0.03 \\
\hline$\theta$ & & & 1.00 & 0.44 \\
\hline$p$ & & & & 1.00 \\
\hline
\end{tabular}

Before discussing the payroll-related propagation mechanism in detail, it is informative to consider other attributes of the artificial economy. Tables 6 and 7 show that the introduction of payroll taxation generates unemployment that not only moves countercyclically, but is also volatile and serially correlated, in line with German joblessness. Likewise, vacancies are strongly cyclical. The volatility of vacancies relative to productivity in the artificial economy increases by about thirtyfold, also taking on a value similar to that in the data. Lastly, Table 7 also suggests that the intertemporal effects of taxes (on search and vacancy choice as well as on wage setting) can help create labor market persistence commonly observed in data: in our artifi- 
cial economy, vacancies and unemployment exhibit autocorrelations much more consistent with empirical observation than the model without labor taxation. ${ }^{20}$

\begin{tabular}{|l|c|c|c|}
\hline \multicolumn{4}{|c|}{ Table 6: Unemployment $(s)$ and vacancies $(v)$} \\
\hline & Germany & Model: $\tau=0$ & Model: $\tau>0$ \\
\hline$\sigma_{v} / \sigma_{y}$ & 13.24 & 1.82 & 12.37 \\
\hline$\sigma_{s} / \sigma_{y}$ & 11.41 & 1.46 & 8.57 \\
\hline$\rho(v, y)$ & 0.67 & 0.61 & 0.99 \\
\hline$\rho(s, y)$ & -0.74 & 0.16 & -0.81 \\
\hline
\end{tabular}

\begin{tabular}{|l|c|c|c|}
\hline \multicolumn{4}{|c|}{ Table 7: Labor market tightness and persistence } \\
\hline & Germany & Model: $\tau=0$ & Model: $\tau>0$ \\
\hline$\sigma_{\theta} / \sigma_{p}$ & 34.52 & 0.99 & 31.47 \\
\hline$\rho(\theta, p)$ & 0.29 & 0.79 & 0.51 \\
\hline$\rho\left(v, v_{-1}\right)$ & 0.95 & 0.31 & 0.82 \\
\hline$\rho\left(s, s_{-1}\right)$ & 0.95 & 0.25 & 0.91 \\
\hline
\end{tabular}

The model's improved performance is evidently related to the countercyclical nature of payroll taxation, which follows directly from the balanced budget restriction and its effect on the wage bargain. Table 8 shows that the introduction of taxes reduces (before tax) wage volatility significantly, with the relative standard deviation of wages declining by almost 50 percent. The wage rises less during booms, and the correlation with output is also cut by half. In effect, the tax system induces rigidity in gross wages paid by employers, even though gross and net wages are perfectly flexible. In Table 8 , we show this directly by comparing wage behavior in the two models.

\begin{tabular}{|l|c|c|}
\hline \multicolumn{2}{|c|}{ Table 8: Wages in the artificial economy } \\
\hline & $\tau=0$ & $\tau>0$ \\
\hline$\sigma_{w} / \sigma_{y}$ & 0.89 & 0.57 \\
\hline$\rho(w, y)$ & 1.00 & 0.52 \\
\hline
\end{tabular}

\footnotetext{
${ }^{20}$ When capital depreciation is held constant, $\rho(s, v)=-0.68, \rho(s, y)=-0.76$, and $\sigma_{\theta} / \sigma_{p}=27.93$, hence while helpful, our results regarding the puzzles do not appear to depend on this feature of the model.
} 
In Figures 5 to 8 we plot impulse responses of the model economy to a single productivity shocks with and without a payroll tax cum social security net. In the presence of taxes, the model becomes substantially more persistent, with output following a humped-shaped pattern. In particular, Figure 7 demonstrates the countercyclical pattern of taxes that arises endogenously in response to a the positive technology shock. Figure 8 displays the relatively rigid response of the wage, which is less volatile than output and dies out rapidly.

Figures 5, 6, 7, and 8 about here

\section{Dissecting and interpreting the mechanism}

Our main findings thus far can be summarized as follows: a calibrated RBC model with labor market frictions combined with an endogenous payroll tax and a distortion of the search-leisure decision can significantly increase endogenous propagation and restore the Beveridge curve without ad hoc assumptions regarding sticky wages, extreme fallback positions or low worker bargaining power.

\subsection{The central role of distortionary payroll taxation}

We claim that the key factor accounting for our results is the dynamic path of payroll taxes as described in Section 2. This being said, it is useful to verify that our artificial economy generates payroll tax sequences similar to those observed in the data. Table 9 shows that the payroll tax in the model economy exhibits relative volatility and countercyclical behavior consistent with the overall intertemporal pattern of payroll tax rates in the data noted in Section 2. While the model's negative correlation of $\tau_{t}$ with output is stronger than in the data, it is important to keep in mind that the model is driven by 
a single shock. Overall, the general mechanism of tax fluctuations that we have uncovered in this paper is qualitatively and quantitatively relevant.

\begin{tabular}{|l|c|c|}
\hline \multicolumn{3}{|c|}{ Table 9: Behavior of payroll tax rate } \\
\hline & Germany & Model with tax \\
\hline$\sigma_{\tau} / \sigma_{y}$ & 1.57 & 1.99 \\
\hline$\rho(\tau, y)$ & -0.51 & -0.92 \\
\hline
\end{tabular}

To demonstrate the importance of the distortionary labor tax channel for generating the model's predictions, we now examine the behavior of our model economy under an alternative financing regime consisting of a constant payroll tax rate $\tau$ and lump sum taxes, $T_{t}$, adjusted each period to obey the government funding constraint

$$
b s_{t}+\varepsilon b\left(1-s_{t}-h_{t}\right)=\tau w_{t} h_{t}+T_{t} .
$$

To maintain the comparability of both models and to isolate the level effect, we impose $T=0$ in the steady state, so $\tau$ assumes the same long-run value as in our baseline calibration. Under these assumptions, the model's previous attributes are restored: persistence falls significantly and the slope of the Beveridge curve changes sign. Vacancies and unemployment are now strongly positively correlated and unemployment is procylical. Characteristic of this outcome is a qualitatively different dynamic behavior of the gross wage. Under the alternative financing arrangement, the correlation of the wage with output rises to 0.99 and its relative volatility nearly doubles. Evidently, the variability of payroll taxes is the central factor driving the results reported in Tables 5-8.

The level of unemployment insurance payments is also important for our results, however. Reducing the replacement rate attenuates the Beveridge curve correlation and ultimately renders it positive (as shown in Table 4). In addition, persistence and volatility of labor market quantities decline sharply. 
The generosity of the social welfare system, parametrized by $\varepsilon$, plays a similar role; reducing $\varepsilon$ lowers the volatility of vacancies and unemployment, while preserving the Beveridge relation. Lower values of $\varepsilon$ reduce the size of the payroll tax burden at any level of employment and the gross wage, thereby reducing the amplitude of $\tau_{t}$ necessary to maintain budget balance at any value of the wage bill. The margin between leisure and search is crucial for generating volatility of labor market quantities; while the effect of lower $\varepsilon$ is ambiguous in theory, the size of the welfare state in the calibrations we study is important for generating our findings. ${ }^{21}$

\subsection{Interpretation}

The model with variable labor taxation offer a better description of the labor market because it induces a relative rigidity of gross wages, i.e. employers' costs, and supports Hall's (2005) claim that fixed wages can align search models and data. ${ }^{22}$ Yet gross and net wages in our artificial economy are endogenous and only appear rigid. Although net wages and the return to work rise in upturns when labor markets are tightening, the negative effects on labor demand and vacancies are dampened by falling payroll taxes. Because gross wages react less strongly, higher employment does not translate as rapidly into higher costs for firms.

Consider a firm which faces a higher realization of total factor productivity, $z_{t}$. Because the posting of vacancies is a dynamic problem, present and future wage labor costs determine the optimal policy via (14). If the gross wage paid by firms remains relatively flat over time, the expected surplus of

\footnotetext{
${ }^{21}$ Note $\tau_{t}=\frac{b\left[s_{t}+\varepsilon\left(1-s_{t}-h_{t}\right)\right]}{w_{t} h_{t}}$, so for fixed $b, s, h$, and $w, \frac{\partial \tau_{t}}{\partial \varepsilon}=\frac{b\left(1-s_{t}-h_{t}\right)}{w_{t} h_{t}}>0$. However, lower values of $\varepsilon$ will affect $s_{t}, h_{t}$ and $w_{t}$, so the general equilibrium effect is theoretically ambiguous.

${ }^{22}$ In the extreme case of a zero workers' bargaining power, i.e. $\mu \rightarrow 0$, the wage (15) does not respond to changes to productivity and it is fixed, given a constant tax rate.
} 
creating jobs will be higher, and firms post more vacancies, which raises their volatility as well. At the same time, countercyclical payroll taxes renders net after-tax wages much less procyclical. Hence, even with sticky wages, workers will see expected benefits from search rise in booms (see Equation 9), but because vacancies respond so strongly, optimal strategy according to (10) involves less search in recessions, not more.

The dampened volatility of gross wages induced by payroll taxes is essential for bringing our model correlations in line with the data (i.e. the consumption-tightness puzzle). As Table 6 shows, the standard model cannot generate countercyclical unemployment. Households respond to a positive productivity shock by moving out of leisure and into search activities, which raises the level of unemployment sharply. In our model, a flatter labor cost profile induces the creation of many more vacancies than in the standard formulation, so while a positive technological shock makes search more attractive, searching workers are moved more rapidly out of leisure and into employment. The result is that any stage of an expansion, fewer agents are unemployed, which is also consistent with empirical evidence that unemployment durations are strongly countercyclical. This is linked to the fact that vacancies become relatively more volatile than search (Table 6) so under the payroll tax regime search unemployment will be countercyclical the combined effect is a correctly sloped Beveridge curve.

\section{Conclusions}

It is well-known that payroll taxes represent a major long-run distortionary influence of governments on labor markets. We have established that they also affect business cycle dynamics. For a number of Western European economies as well as the United States for last two decades, the average pay- 
roll tax burden has been countercyclical. ${ }^{23}$ Although we consider a specific type of labor tax here, its behavior is consistent with Rogerson and Shimer's (2010) description of a countercyclical labor wedge. Our study takes up the role of payroll taxation and the social safety net - modeled as a generous system of unemployment insurance - for cyclical fluctuations in an nonmonetary economy with labor market frictions and unemployment insurance, when the latter is only imperfectly related to search effort. A balanced social insurance budget renders gross wages more rigid over the cycle and, as a result, strengthens the model's endogenous propagation mechanism. The existence of social insurance strengthens this effect, as does worker bargaining power. For conventional calibrations, the model can generate a negatively sloped Beveridge curve and match the high volatility of vacancies and unemployment relative to labor productivity. While it is beyond the scope of this study, it would be useful to examine micro data and uncover the quantitative sources of countercyclical payroll taxation and to account for its behavior over time.

It was not the purpose of this paper to produce a general account of the high volatility of vacancies and unemployment in modern economies, but we have identified a new mechanism which can help us better understand the labor market and its interaction with the business cycle. Countercyclical taxation of labor can contribute towards resolving the Hall-Shimer puzzle and realign theory with many labor market facts, but need not be the only mechanism which does so, and evidence presented in Table 1 suggests that a large number of forces may be at work in creating observed outcomes. Our results for artificial economies imply that payroll taxes combined with a

\footnotetext{
${ }^{23}$ If we set $\varepsilon$ so the model matches average $\tau$ in the US and steady state unemployment equals five percent, our artificial economy's Beveridge correlation is $\rho(u, v)=-0.45$ (versus 0.83 without variable payroll tax) and $\sigma_{\theta} / \sigma_{p}=6.23$ (versus 1.76 without variable payroll tax).
} 
high subsidy of leisure can significantly affect the qualitative properties of an important class of equilibrium business cycle models, and it would be easy to identify other tax and transfer mechanisms that work in a similar fashion, in particular, more general systems of labor taxation in which a balanced budget constraint is operative in each period. The novel aspects of our model mimic a particular facet of many OECD labor markets, and for the US in the latter half of our sample. Without payroll taxes, our model would still exhibit the anomaly identified by Ravn (2008). The payroll tax mechanism, combined with a sufficiently large social insurance system, represents a simple means of accounting for central relative variances in the data while incorporating an important feature of modern labor markets. 


\section{References}

[1] Beveridge, William H. (1944): "The Government's Employment Policy," Economic Journal 54, 161-176.

[2] Bils, Mark (1985) "Real Wages over the Business Cycle: Evidence from Panel Data" Journal of Political Economy 93: 666-89.

[3] Burda, Michael C. and Mark Weder (2002): "Complementarity of Labor Market Institutions, Equilibrium Unemployment and the Persistence of Business Cycles", German Economic Review 3, 1-24.

[4] Burda, Michael C., Dan S. Hamermesh and Philippe Weil (2008): "The Distribution of Total Work in the EU and the US," in Tito Boeri, et al. eds., Working Hour and Job Sharing in the EU and the USA: Are Europeans Lazy or Americans Crazy?, Oxford: Oxford University Press.

[5] Chari, V. V., Patrick J. Kehoe and Ellen R. McGrattan (2008): "Business Cycle Accounting", Econometrica 75, 781-836.

[6] Cole, Harold L. and Richard Rogerson (1999): "Can the MortensenPissarides Matching Model Match the Business-Cycle Facts?," International Economic Review 40, 933-59.

[7] Cooley, Thomas F. (1997): "Calibrated Models", Oxford Review of Economic Policy 13, 55-69.

[8] Costain, Jim and Michael Reiter (2008): "Business Cycles, Unemployment Insurance, and the Calibration of Matching Models," Journal of Economic Dynamics and Control 32:1120-1155.

[9] Ebell, Monique (2009): "Resurrecting the Participation Margin", mimeo. 
[10] Galí, Jordi and Thijs van Rens (2010): "The Vanishing Procyclicality of Labor Productivity," mimeo, July 2010.

[11] Gartner, Hermann, Christian Merkl and Thomas Rothe (2009): "They are Even Larger! More (on) Puzzling Labor Market Volatilities", IZA Discussion Paper 4403.

[12] Gertler, Mark and Antonella Trigari (2009): "Unemployment Fluctuations with Staggered Nash Wage Bargaining", Journal of Political Economy 117, 38-86.

[13] Greenwood, Jeremy, Zvi Hercowitz and Gregory Huffman (1988): "Investment, Capacity Utilization, and the Real Business Cycle", American Economic Review 78, 402-417.

[14] Hagedorn, Marcus and Iourii Manovskii (2008): "The Cyclical Behavior of Equilibrium Unemployment and Vacancies Revisited", American Economic Review 98, 1692-1706.

[15] Hall, Robert (2005): "Employment Fluctuations with Equilibrium Wage Stickiness", American Economic Review 95, 50-65.

[16] Hall, Robert and Paul R. Milgrom (2008): "The Limited Influence of Unemployment on the Wage Bargain", American Economic Review 98, 1653-1674.

[17] Hornstein, Andreas, Per Krusell and Giovanni L. Violante (2005): "Unemployment and Vacancy Fluctuations in the Matching Model: Inspecting the Mechanism", Federal Reserve Bank of Richmond Economic Quarterly 91, 19-51.

[18] Hosios, A. (1990): "On the Efficiency of Matching and Related Models of Search and Unemployment," Review of Economic Studies 57, 279-298. 
[19] Kaldor, Nicholas (1936): "Wage Subsidies as a Remedy for Unemployment," Journal of Political Economy 44, 721-742.

[20] Keynes, John M. (1942): letter to James Meade in: Kenyes, John Maynard (1980). The Collected Writings of John Maynard Keynes Volume 27. Edited by Donald Moggridge. Macmillan, Cambridge University Press, 217-8.

[21] Meade, James (1938): Consumers' Credits and Unemployment, Oxford: Oxford University Press.

[22] Merz, Monika (1995): "Search in the labor market and the real business cycle," Journal of Monetary Economics 36, 269-300.

[23] Ravn, Morten (2008): "The Consumption-Tightness Puzzle", in: Reichlin, Lucrecia and West, Kenneth (eds.) NBER International Seminars in Macroeconomics, Chicago: University of Chicago Press.

[24] Rogerson, Richard and Robert Shimer (2010): "Labor Search", in Handbook of Labor Economics, forthcoming.

[25] Romer, David and Christina Romer (2009): "A Narrative Analysis of Postwar Tax Changes", (Appendix to "The Macroeconomic Effects of Tax Changes: Estimates Based on a New Measure of Fiscal Shocks.")

[26] Shimer, Robert (2005): "The Cyclical Behavior of Equilibrium Unemployment and Vacancies," American Economic Review 95, 25-49.

[27] Shimer, Robert (2009): Labor Markets and Business Cycles, manuscript, University of Chicago.

[28] Tripier, Fabien (2003): "Can the Labor Market Search Model Explain Fluctuations of Allocations of Time?", Economic Modeling 21, 131-46. 
[29] Veracierto, Marcelo (2008): "On the Cyclical Behavior of Employment, Unemployment and Labor Force Participation", Journal of Monetary Economics 55, 1143-57. 


\section{Appendix: Wage equation}

The first order condition from the Nash bargaining problem is

$$
\frac{\mu\left(1-\tau_{t}\right)}{c_{t} V_{h_{t}}}=\frac{(1-\mu)}{W_{h_{t}}}
$$

or, given that the value of an additional employed worker to the firm is given by

$$
c_{t} V_{h_{t}}=\frac{\mu\left(1-\tau_{t}\right)}{1-\mu}\left[(1-\alpha) \frac{y_{t}}{h_{t}}-w_{t}+\left(1-\delta^{n}\right) \frac{a}{q_{t}}\right]
$$

Lead this expression by one period and premultiply by the pricing kernel $\rho_{t+1}$ :

$$
\rho_{t+1} c_{t+1} V_{h_{t+1}}=\frac{\mu\left(1-\tau_{t+1}\right)}{1-\mu} \rho_{t+1}\left[(1-\alpha) \frac{y_{t+1}}{h_{t+1}}-w_{t+1}+\left(1-\delta^{n}\right) \frac{a}{q_{t+1}}\right] .
$$

Take expectation of both sides conditional on $t$, and the fact that $\rho_{t+1} c_{t+1}=$ $\beta c_{t}$ to rewrite the last expression as

$$
E_{t} \rho_{t+1} c_{t+1} V_{h_{t+1}}=\beta c_{t} E_{t} V_{h_{t+1}}=\frac{\mu E_{t}\left(1-\tau_{t+1}\right)}{1-\mu} \frac{a}{q_{t}}
$$

Premultiply both sides of the household surplus from employment by $c_{t}$, substitute the last expression and use $\rho_{t+1}=\beta c_{t} / c_{t+1}$ to obtain

$$
c_{t} V_{h_{t}}=\left(1-\tau_{t}\right) w_{t}-b+\rho_{t+1}\left(1-\delta^{n}-f_{t}\right) c_{t+1} E_{t} V_{h_{t+1}}
$$

and

$$
c_{t} V_{h_{t}}=\left(1-\tau_{t}\right) w_{t}-b+\left(1-\delta^{n}-f_{t}\right) \frac{\mu E_{t}\left(1-\tau_{t+1}\right)}{1-\mu} \frac{a c_{t}}{q_{t}}
$$

Now insert this and (A1) into the Nash bargaining first-order condition:

$$
\begin{aligned}
& \mu\left(1-\tau_{t}\right)\left[(1-\alpha) \frac{y_{t}}{h_{t}}-w_{t}+\left(1-\delta^{n}\right) \frac{a}{q_{t}}\right] \\
= & (1-\mu)\left[\left(1-\tau_{t}\right) w_{t}-b+\left(1-\delta^{n}-f_{t}\right) \frac{\mu E_{t}\left(1-\tau_{t+1}\right)}{1-\mu} \frac{a}{q_{t}}\right]
\end{aligned}
$$


which can be solved to obtain

$$
w_{t}=\frac{(1-\mu) b}{1-\tau_{t}}+\mu(1-\alpha) \frac{y_{t}}{h_{t}}+\mu\left(1-\delta^{n}\right) \frac{a}{q_{t}}-\mu\left(1-\delta^{n}-f_{t}\right) \frac{a}{q_{t}} \frac{E_{t}\left(1-\tau_{t+1}\right)}{1-\tau_{t}}
$$

or

$$
w_{t}=\frac{(1-\mu) b}{1-\tau_{t}}+\mu(1-\alpha) \frac{y_{t}}{h_{t}}+\mu\left(1-\delta^{n}\right) \frac{a}{q_{t}} \frac{E_{t}\left(\tau_{t+1}-\tau_{t}\right)}{1-\tau_{t}}+\mu \theta_{t} a \frac{E_{t}\left(1-\tau_{t+1}\right)}{1-\tau_{t}} .
$$


Figure 1: Payroll taxes as a fraction of total compensation, United States, 1970:I-2008:IV

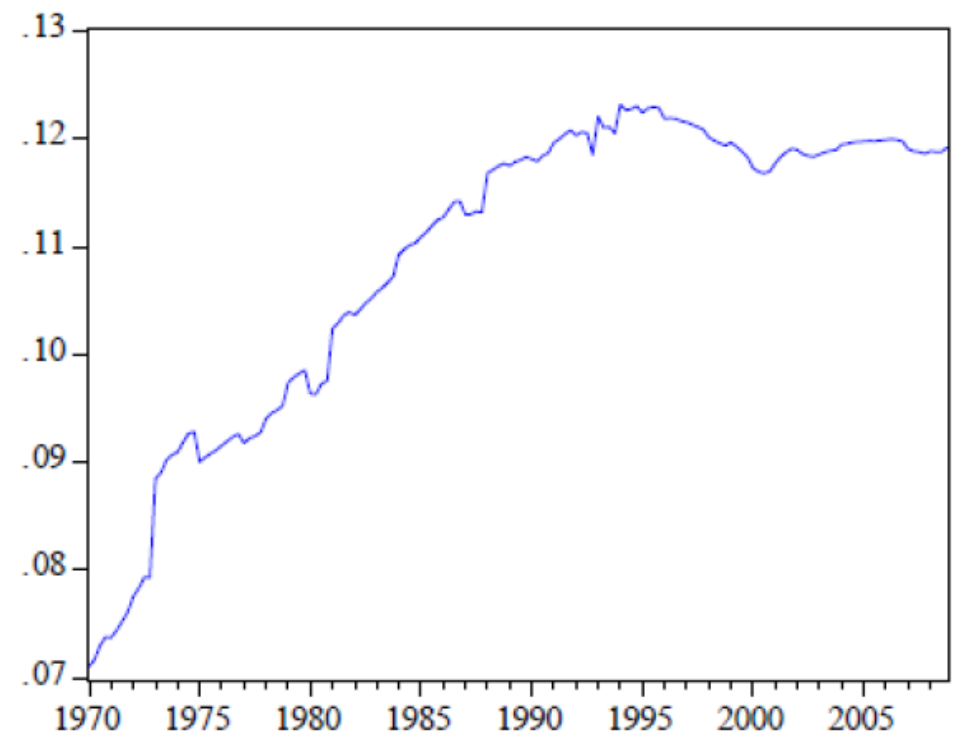

Figure 2: Payroll taxes as a fraction of total compensation, Germany 1970:I2008:IV

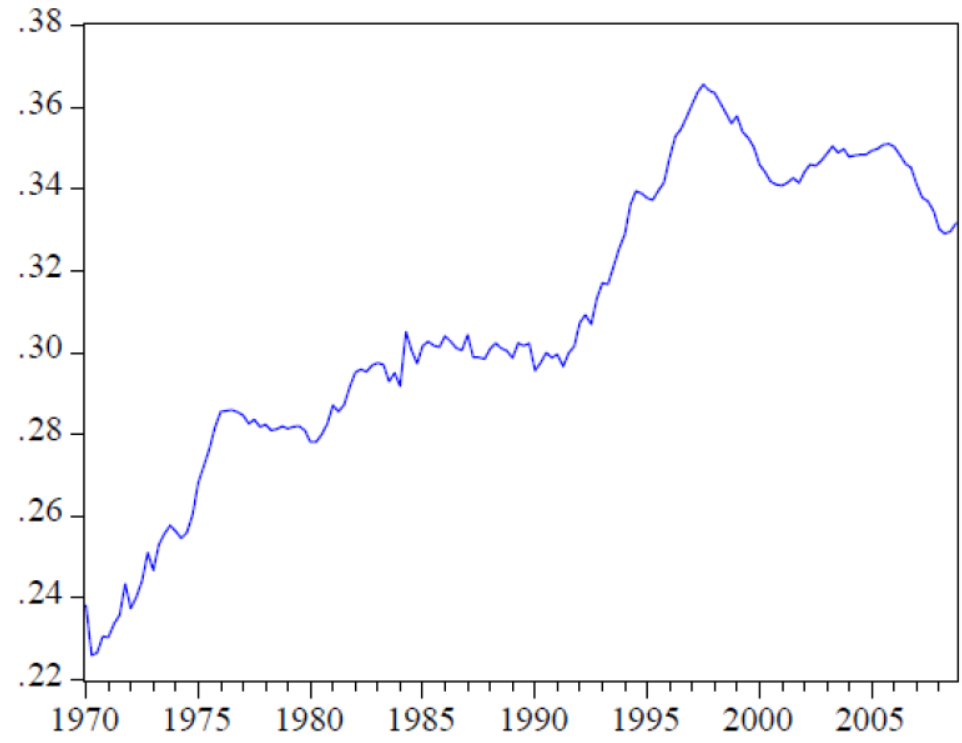


Figure 3: HP-detrended payroll taxes and GDP per capita, United States, 1970:I-2008:IV

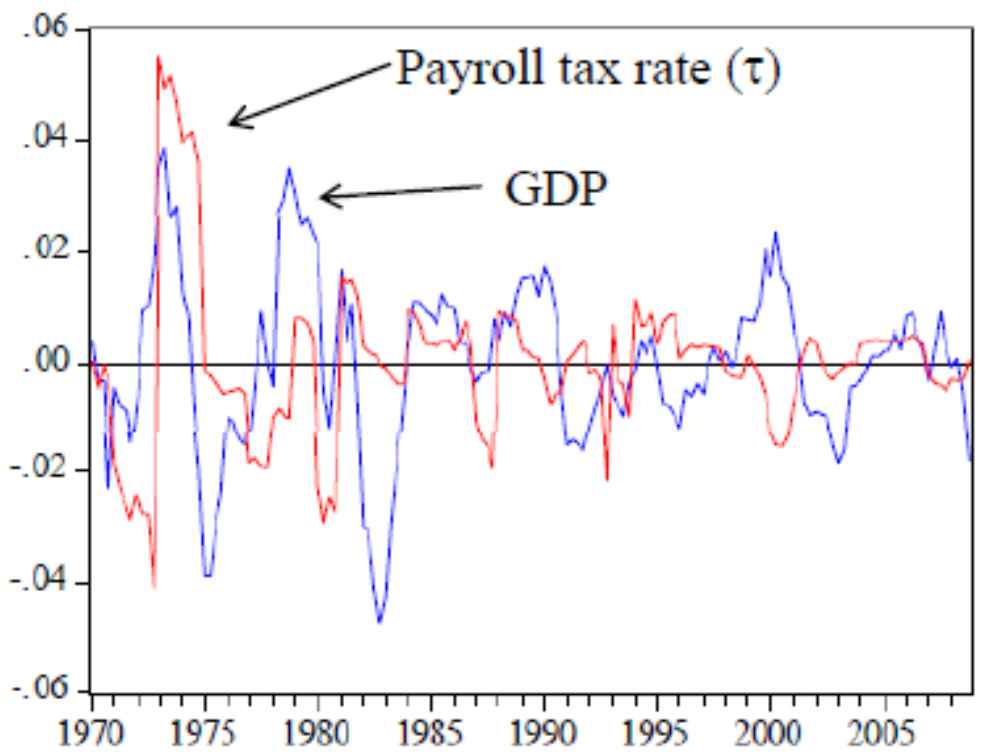

Figure 4: HP-detrended payroll taxes and GDP per capita, Germany 1970:I2008:IV

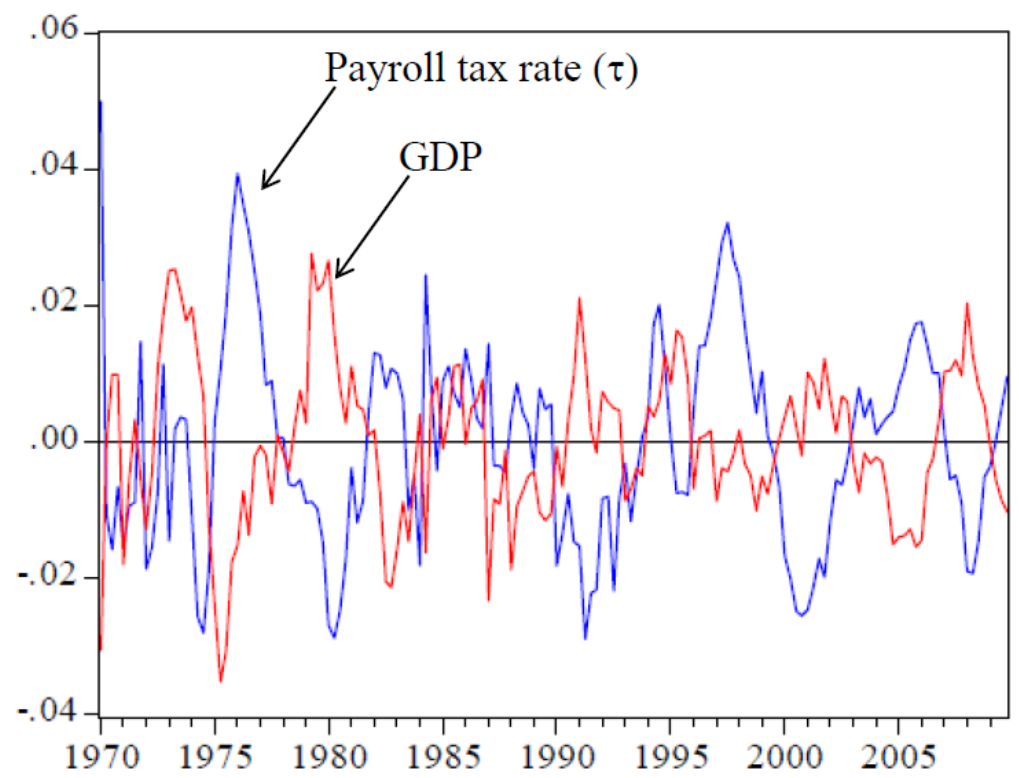


Figure 5: Impulse response functions (IRF) of the model economy without payroll taxes and social insurance system to a positive $1 \%$ technology shock $(\mathrm{z})$ : Output, unemployment, labor share
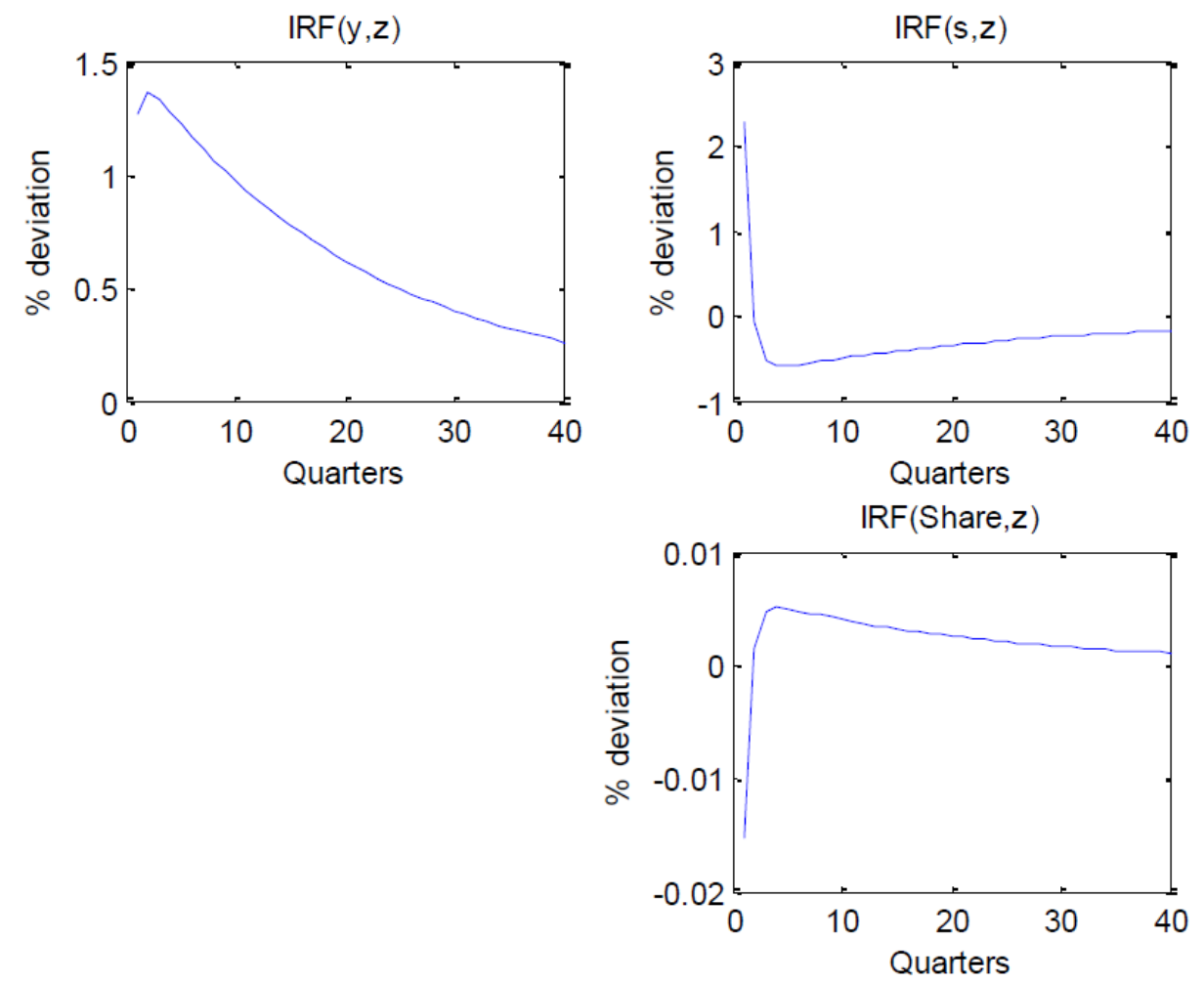
Figure 6: Impulse response functions (IRF) of the model economy without payroll taxes and social insurance system to a positive $1 \%$ technology shock $(\mathrm{z})$ : Vacancies, employment, wages, labor market tightness (v/s)
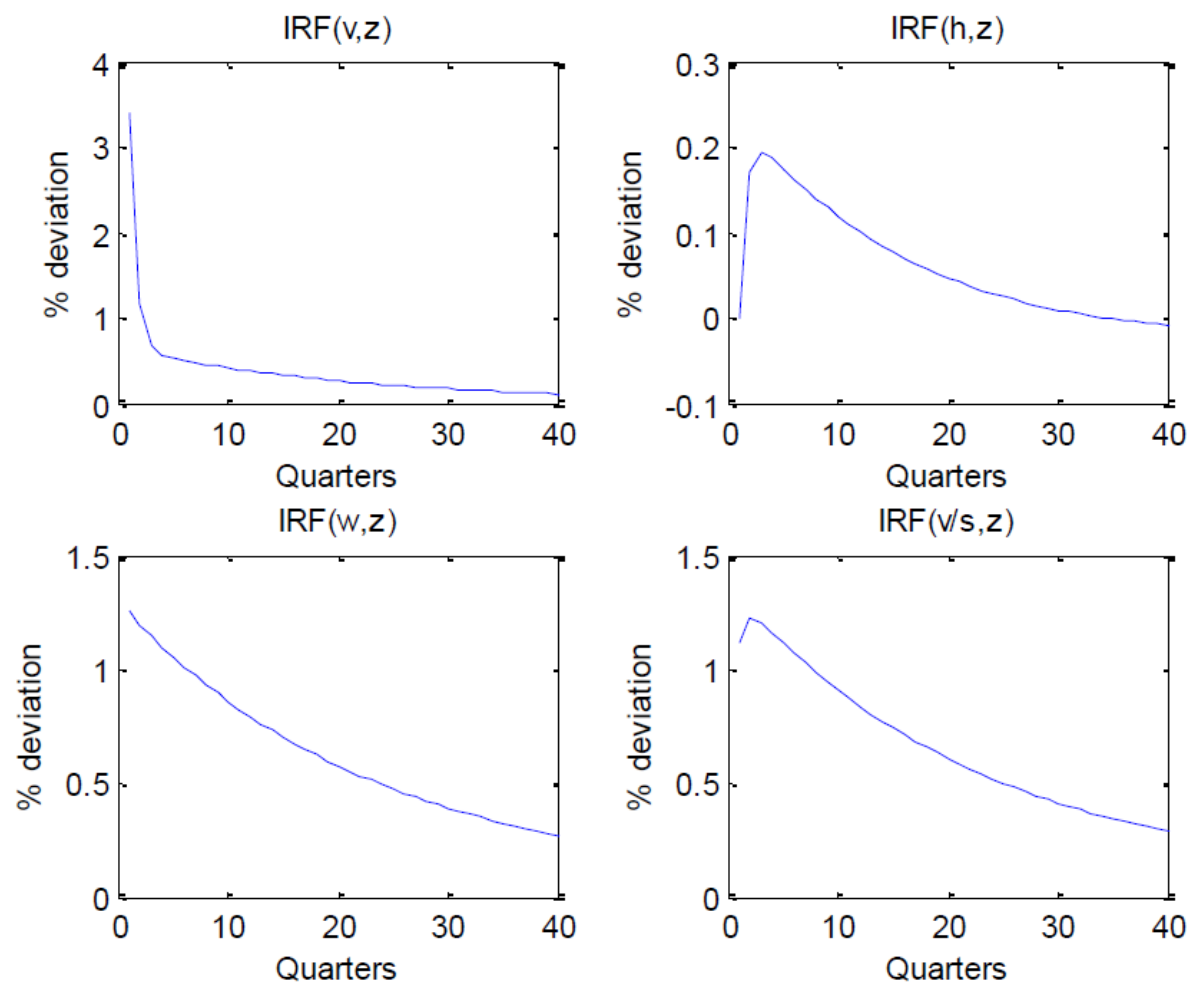
Figure 7: Impulse response functions (IRF) of the model economy with payroll taxes and social insurance system to a positive $1 \%$ technology shock: Output, unemployment, tax rate, labor share
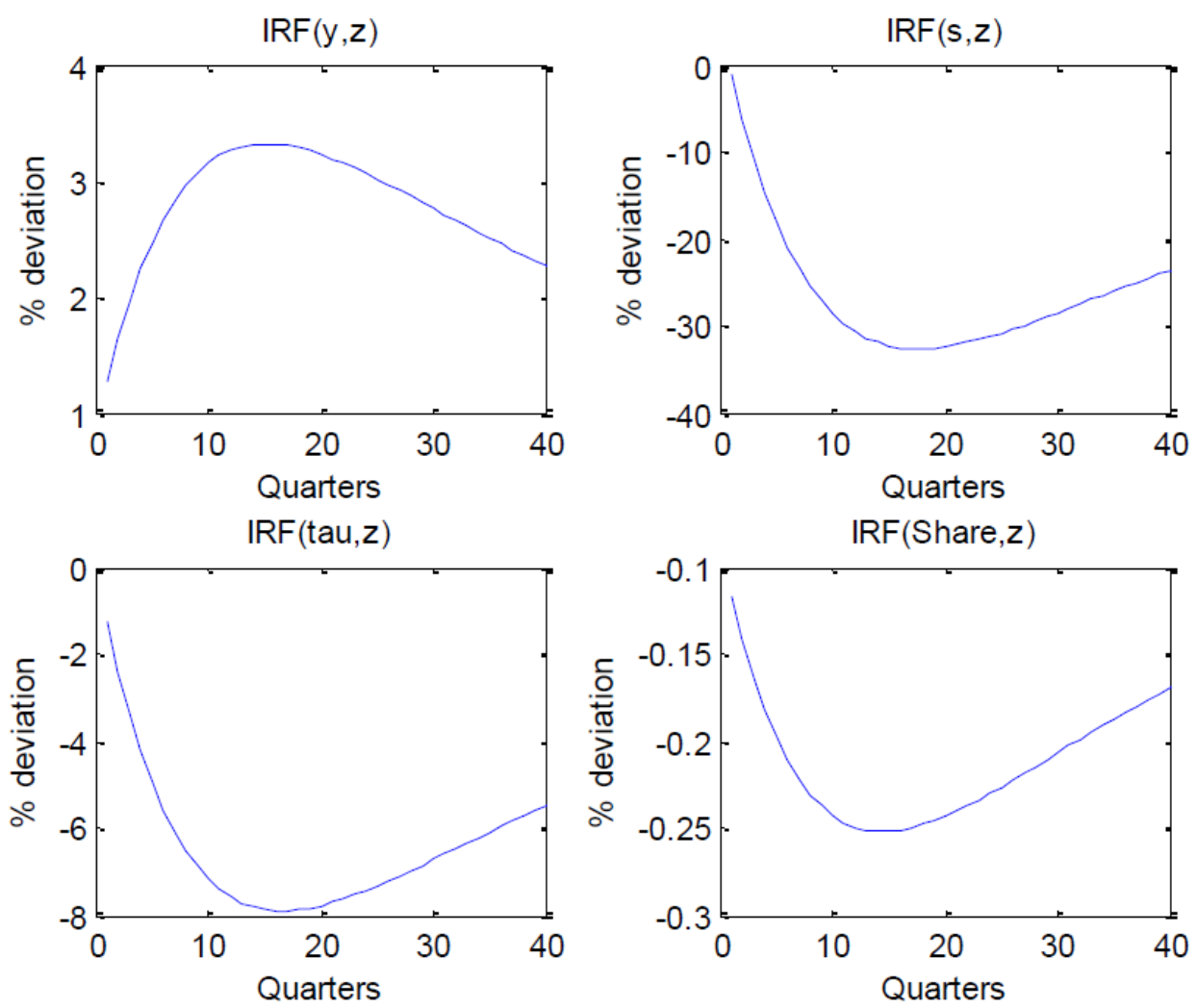
Figure 8: Impulse response functions (IRF) of the model economy with payroll taxes and social insurance system to a positive 1\% technology shock: Vacancies, employment, wages, labor market tightness $(\mathrm{v} / \mathrm{s})$
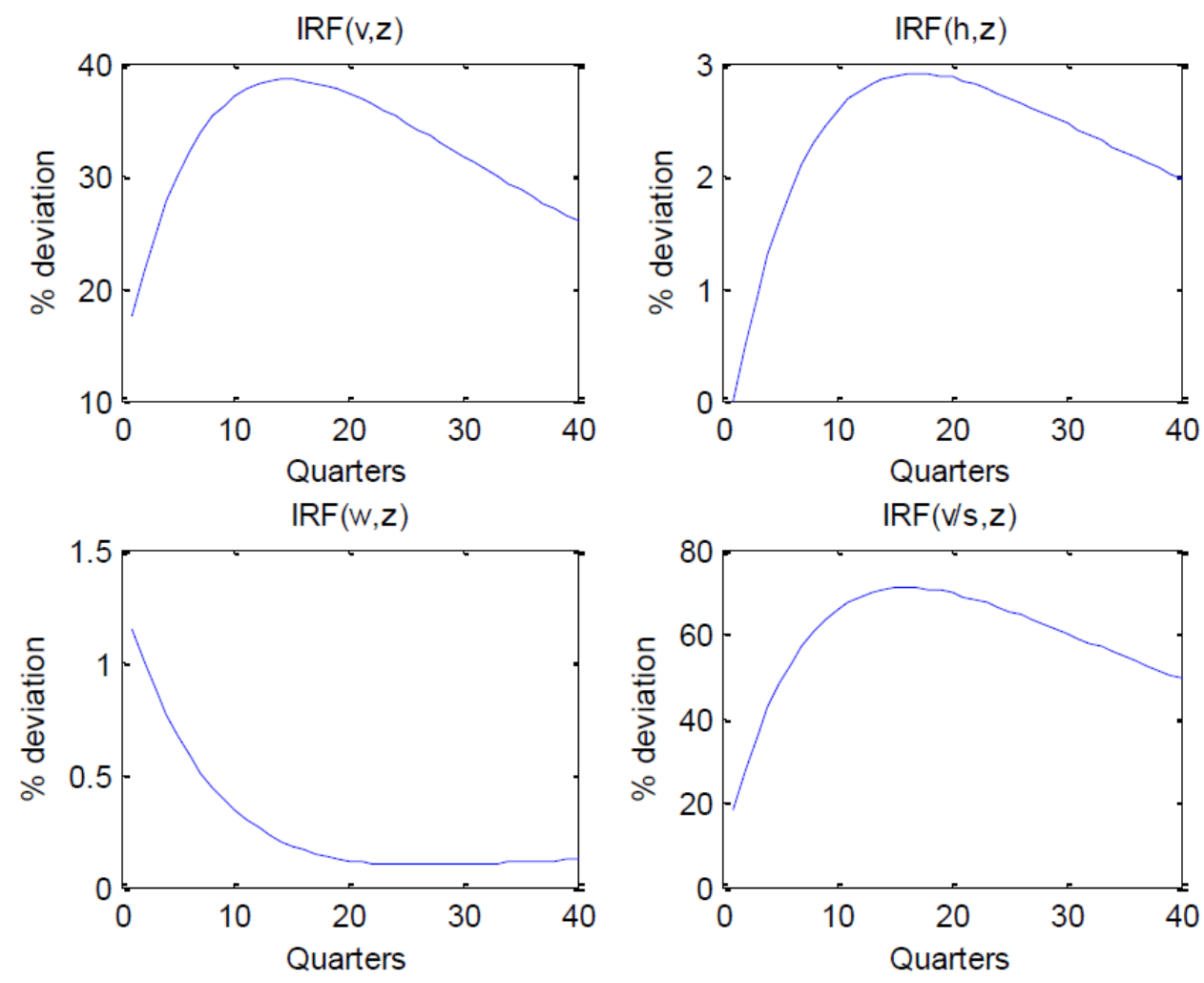


\section{SFB 649 Discussion Paper Series 2010}

For a complete list of Discussion Papers published by the SFB 649, please visit http://sfb649. wiwi.hu-berlin. de.

001 "Volatility Investing with Variance Swaps" by Wolfgang Karl Härdle and Elena Silyakova, January 2010.

002 "Partial Linear Quantile Regression and Bootstrap Confidence Bands" by Wolfgang Karl Härdle, Ya'acov Ritov and Song Song, January 2010.

003 "Uniform confidence bands for pricing kernels" by Wolfgang Karl Härdle, Yarema Okhrin and Weining Wang, January 2010.

004 "Bayesian Inference in a Stochastic Volatility Nelson-Siegel Model" by Nikolaus Hautsch and Fuyu Yang, January 2010.

005 "The Impact of Macroeconomic News on Quote Adjustments, Noise, and Informational Volatility" by Nikolaus Hautsch, Dieter Hess and David Veredas, January 2010.

006 "Bayesian Estimation and Model Selection in the Generalised Stochastic Unit Root Model" by Fuyu Yang and Roberto Leon-Gonzalez, January 2010.

007 "Two-sided Certification: The market for Rating Agencies" by Erik R. Fasten and Dirk Hofmann, January 2010.

008 "Characterising Equilibrium Selection in Global Games with Strategic Complementarities" by Christian Basteck, Tijmen R. Daniels and Frank Heinemann, January 2010.

009 "Predicting extreme VaR: Nonparametric quantile regression with refinements from extreme value theory" by Julia Schaumburg, February 2010.

010 "On Securitization, Market Completion and Equilibrium Risk Transfer" by Ulrich Horst, Traian A. Pirvu and Gonçalo Dos Reis, February 2010.

011 "Illiquidity and Derivative Valuation" by Ulrich Horst and Felix Naujokat, February 2010.

012 "Dynamic Systems of Social Interactions" by Ulrich Horst, February 2010.

013 "The dynamics of hourly electricity prices" by Wolfgang Karl Härdle and Stefan Trück, February 2010.

014 "Crisis? What Crisis? Currency vs. Banking in the Financial Crisis of 1931" by Albrecht Ritschl and Samad Sarferaz, February 2010.

015 "Estimation of the characteristics of a Lévy process observed at arbitrary frequency" by Johanna Kappusl and Markus Reiß, February 2010.

016 "Honey, I'll Be Working Late Tonight. The Effect of Individual Work Routines on Leisure Time Synchronization of Couples" by Juliane Scheffel, February 2010.

017 "The Impact of ICT Investments on the Relative Demand for HighMedium-, and Low-Skilled Workers: Industry versus Country Analysis" by Dorothee Schneider, February 2010.

018 "Time varying Hierarchical Archimedean Copulae" by Wolfgang Karl Härdle, Ostap Okhrin and Yarema Okhrin, February 2010.

019 "Monetary Transmission Right from the Start: The (Dis)Connection Between the Money Market and the ECB's Main Refinancing Rates" by Puriya Abbassi and Dieter Nautz, March 2010.

020 "Aggregate Hazard Function in Price-Setting: A Bayesian Analysis Using Macro Data" by Fang Yao, March 2010.

021 "Nonparametric Estimation of Risk-Neutral Densities" by Maria Grith, Wolfgang Karl Härdle and Melanie Schienle, March 2010. 


\section{SFB 649 Discussion Paper Series 2010}

For a complete list of Discussion Papers published by the SFB 649, please visit http://sfb649. wiwi.hu-berlin.de.

022 "Fitting high-dimensional Copulae to Data" by Ostap Okhrin, April 2010.

023 "The (In)stability of Money Demand in the Euro Area: Lessons from a Cross-Country Analysis" by Dieter Nautz and Ulrike Rondorf, April 2010.

024 "The optimal industry structure in a vertically related market" by Raffaele Fiocco, April 2010.

025 "Herding of Institutional Traders" by Stephanie Kremer, April 2010.

026 "Non-Gaussian Component Analysis: New Ideas, New Proofs, New Applications" by Vladimir Panov, May 2010.

027 "Liquidity and Capital Requirements and the Probability of Bank Failure" by Philipp Johann König, May 2010.

028 "Social Relationships and Trust" by Christine Binzel and Dietmar Fehr, May 2010.

029 "Adaptive Interest Rate Modelling" by Mengmeng Guo and Wolfgang Karl Härdle, May 2010.

030 "Can the New Keynesian Phillips Curve Explain Inflation Gap Persistence?" by Fang Yao, June 2010.

031 "Modeling Asset Prices" by James E. Gentle and Wolfgang Karl Härdle, June 2010.

032 "Learning Machines Supporting Bankruptcy Prediction" by Wolfgang Karl Härdle, Rouslan Moro and Linda Hoffmann, June 2010.

033 "Sensitivity of risk measures with respect to the normal approximation of total claim distributions" by Volker Krätschmer and Henryk Zähle, June 2010.

034 "Sociodemographic, Economic, and Psychological Drivers of the Demand for Life Insurance: Evidence from the German Retirement Income Act" by Carolin Hecht and Katja Hanewald, July 2010.

035 "Efficiency and Equilibria in Games of Optimal Derivative Design" by Ulrich Horst and Santiago Moreno-Bromberg, July 2010.

036 "Why Do Financial Market Experts Misperceive Future Monetary Policy Decisions?" by Sandra Schmidt and Dieter Nautz, July 2010.

037 "Dynamical systems forced by shot noise as a new paradigm in the interest rate modeling" by Alexander L. Baranovski, July 2010.

038 "Pre-Averaging Based Estimation of Quadratic Variation in the Presence of Noise and Jumps: Theory, Implementation, and Empirical Evidence" by Nikolaus Hautsch and Mark Podolskij, July 2010.

039 "High Dimensional Nonstationary Time Series Modelling with Generalized Dynamic Semiparametric Factor Model" by Song Song, Wolfgang K. Härdle, and Ya'acov Ritov, July 2010.

040 "Stochastic Mortality, Subjective Survival Expectations, and Individual Saving Behavior" by Thomas Post and Katja Hanewald, July 2010.

041 "Prognose mit nichtparametrischen Verfahren" by Wolfgang Karl Härdle, Rainer Schulz, and Weining Wang, August 2010.

042 "Payroll Taxes, Social Insurance and Business Cycles" by Michael C. Burda and Mark Weder, August 2010. 